\title{
VIRULENCE AND PRE-LETHAL REPRODUCTIVE EFFECTS OF Metarhizium anisopliae var. anisopliae ON Pseudococcus viburni (HEMIPTERA: PSEUDOCOCCIDAE)
}

\author{
Aldo Pereira ${ }^{1 *}$, Pedro Casals ${ }^{1}$, Ana María Salazar ${ }^{2}$, and Marcos Gerding ${ }^{2}$
}

\begin{abstract}
Obscure mealybug, Pseudococcus viburni (Signoret), is a cosmopolitan pest that causes damage by suction of vascular juices and the production of honeydew, as well as for being a quarantine insect. Within control options, entomopathogenic fungi are a good alternative, nevertheless, more research is needed. In this research, the Metarhizium anisopliae var. anisopliae (Metschnikoff) isolate Qu-M984 was evaluated on P. viburni under laboratory conditions. Virulence was evaluated by lethal dose $50\left(\mathrm{LD}_{50}\right)$ and lethal time $50\left(\mathrm{LT}_{50}\right)$, for each of the four life stages of the female. The doses tested were $10^{5}, 10^{6}$, $10^{7}$ and $10^{8}$ conidia $\mathrm{mL}^{-1}$. Also fecundity, egg size, fertility, and longevity of adult females were evaluated at doses of $10^{5}$ and $10^{6}$ conidia $\mathrm{mL}^{-1}$, the evaluations were made every $2 \mathrm{~d}$ throughout the insect life time. The $\mathrm{LD}_{50}$ and $\mathrm{LT}_{50}$ obtained were variable for each life stage, although without statistical differences among life stages $(\mathrm{P}>0.05)$, ranging from $\mathrm{LD}_{50}=7.3 \times$ $10^{5}$ to $4.9 \times 10^{9}$ conidia $\mathrm{mL}^{-1}$ and $\mathrm{LT}_{50}=7.74$ to $9.97 \mathrm{~d}$ at $10^{8}$ conidia $\mathrm{mL}^{-1}$. Significant differences $(\mathrm{P} \leq 0.05)$ were observed on longevity at $10^{6}$ conidia $\mathrm{mL}^{-1}$. Longevity was $29 \%$ less compared to the control. This result on longevity at relatively low dose is relevant due to the fact that decrease possibilities to find live quarantine insects at the moment of harvest. Fertility, fecundity and egg size showed no differences $(\mathrm{P}>0.05)$.
\end{abstract}

Key words: Lethal dose, lethal time, biological control, entomopathogenic fungus, fecundity, fertility, longevity.

$P$ seudococcus viburni Signoret (Hemiptera: Pseudococcidae), commonly named obscure mealybug, is a cosmopolitan insect present in temperate climates areas of the Northern Hemisphere, South Africa, Australia, New Zealand, and Chile (González et al., 2001). It is polyphagous, attacking ornamentals, fruit trees, forest trees, and cactus. It has an oval and wax covered body. The direct damage is produced by suction of vascular juices and the production of sweet honeydew (González, 1989). The affected parts of the plant present a dark oily aspect, due to the sweet honeydew that is infected by fungus and dust, commonly named sooty mould (Artigas, 1994), which greatly depreciates the quality of fruit such as table grapes (Vitis vinifera L.) (Bournier, 1976). Obscure mealybug is a quarantine insect of mandatory control that hides in places of difficult access (González, 2003b). Most Pseudococcus species cause low direct damage and are considered minor plagues, and major plagues for being quarantine insects on grapes, pomaceous, and stone fruit (González, 2003a). The markets with quarantine restriction to $P$. viburni are Brazil, Mexico, Japan, and Korea (González and Volosky, 2006). Within insect pathogens, entomopathogenic fungi are the main contenders for commercial production

${ }^{1}$ Universidad de Concepción, Facultad de Agronomía, Casilla 537, Chillán, Chile. "Corresponding author (apereirav@udec.cl).

${ }^{2}$ Instituto de Investigaciones Agropecuarias INIA, Casilla 426, Chillán, Chile.

Received: 15 March 2011.

Accepted: 25 August 2011. and use against homopterous pest insects (Lacey et al., 2001). Entomopathogenic fungi do not cause immediate mortality. The activity of infected hosts can be altered just before death due to microbial infections (Hajek et al., 2008).

A minimal amount of pathogen exists to start a disease (Alves and Lecuona, 1998), as well as a positive correlation between infectious conidia and mortality by mycosis (Ferron, 1978). There are sublethal effects that can affect the reproductive output of infected adult females with entomopathogenic fungi before death (Roy et al., 2006). On the other hand, this infection does not have always the same effect on reproduction, being able to present a decrease or increase on fecundity, as well as a decrease on longevity (Hajek et al., 2008). Whereas the majority of studies assessing biocontrol agents deal with their ability to produce mortality in the target pest, a considerable number have also being assessed for the impact that infection may produce on host behaviors. These include effects on developmental time, fecundity and feeding (Blanford and Thomas, 2001). Different studies with entomopathogenic fungi have shown effects over the reproductive potential of infected females. Castillo et al. (2000) show that Metarhizium anisopliae affect females fecundity of Ceratitis capitata Wiedemann, as well as Blatella germanica (Linneo) (Quesada-Moraga et al., 2004) and Anopheles gambiae (Giles) (Scholte et al., 2006), among other species. 
The aim of this research was to evaluate the virulence of different doses of M. anisopliae var. anisopliae isolate Qu-M984 on developmental stages of P. viburni and the pre-lethal effects fertility, egg size, fecundity, and longevity on the adult female.

\section{MATERIALS AND METHODS}

\section{Insects}

Pseudococcus viburni Signoret (Hemiptera: Pseudococcidae) were obtained from an artificial mass rearing unit maintained since 2005 by Instituto de Investigaciones Agropecuarias INIA Quilamapu (Chillán, Chile). Insects were reared on potato (Solanum tuberosum L.) buds and held in total darkness at $23 \pm 1$ ${ }^{\circ} \mathrm{C}$ and $80 \% \pm$ R.H. The four developmental stages were used for experimentation and the selection criteria was the movement capacity and acceptable healthy. The three nymph stages and adult females were identified under stereomicroscope of $40 \mathrm{X}$, according to insect size and presence of marginal filaments, using the classification of the four developmental stages of $P$. viburni females described by Oyarzún (2004).

\section{Conidial production}

Metarhizium anisopliae var. anisopliae isolate Qu-M984, was obtained from the entomopathogenic fungi collection in INIA Quilamapu (Chillán, Chile). The fungus was cultivated on potato dextrose agar (PDA) medium in Petri dishes, inoculated in biological safety cabinet and placed in an incubator at $25^{\circ} \mathrm{C}$ for $2 \mathrm{wk}$ in complete darkness until sporulation. Conidia were harvested directly by scraping from the surface culture and suspended in sterile distilled water containing $0.01 \%$ Tween 80 (Sigma ${ }^{\circledR}$, Steinheim, Germany) to produce a homogenous suspension. The concentration of the suspension was determined by using a haemocytometer (BOECO, Neubauer, Germany) under microscope 1000X, and diluted with sterile distilled water plus $0.01 \%$ Tween 80 to obtain the conidial concentrations for each trial.

\section{Virulence}

Insects of the four developmental stages were placed on cylindrical flasks of $39 \mathrm{~mL}$ and sprayed with the doses $10^{5}, 10^{6}, 10^{7}$ and $10^{8}$ conidia $\mathrm{mL}^{-1}$, the control was treated with sterile distilled water. All treatments contained $0.01 \%$ Tween 80 . A Potter spray tower at $0.1 \mathrm{MPa}$ was used to apply the conidia over the individuals that were immediately transferred to a piece of potato buds serving as food and maintained at $23 \pm 1{ }^{\circ} \mathrm{C}$ in the dark. Mortality was recorded for each individual every $2 \mathrm{~d}$ until $19 \mathrm{~d}$ post application. All dead insects were placed individually in a humid chamber at $25^{\circ} \mathrm{C}$ to facilitate the appropriate sporulation of $M$. anisopliae on the insect surface to confirm mycosis (Butt and Goettel, 2000). The criteria to determine mortality was the response to mechanical stimuli, being considered dead insects those with no evident reaction.

The experimental design was completely randomized, with five treatments and four replicates, each experimental unit consisting of 10 insects, for each of the four developmental stages of the female. Mortality rates were separated by Tukey test $(\mathrm{P}<0.05)$ and compared by oneway ANOVA using the statistical program SAS (SAS Institute, 2003). The recorded means of mortality were corrected using Abbott formula (Abbott, 1925). Lethal dose $\left(\mathrm{LD}_{50}\right)$ and lethal time $\left(\mathrm{LT}_{50}\right)$ were estimated using Probit analysis (Statgraphics, 2000). Fit of the regression lines were verifying using $\chi^{2}$ test (SAS Institute, 2003).

\section{Pre-lethal effects}

Fertility and egg size. The doses used on the trials of fertility, egg size, longevity, and fecundity were $10^{5}$ and $10^{6}$ conidia $\mathrm{mL}^{-1}$. Control individuals were treated with sterile distilled water. All treatments contained Tween 80 at $0.01 \%$. The low doses $10^{5}$ and $10^{6}$ conidia $\mathrm{mL}^{-1}$ were selected to increase possibilities of a slow infection by the fungus in the insect and analize sublethal effects before death, avoiding a high and quick mortality. Insects selected were adult females. Egg fertility was estimated registering the eclosion of eggs by number of nymphs emerged, checking the total eclosed and non eclosed eggs as well as the empty chorion left by eclosed eggs. The recorded means were analyzed using Chi-square test with an experimental unit of 25 eggs per female (SAS Institute, 2003). Egg size was recorded by taking samples of 25 eggs for each female, separating the wax and placing them in horizontal position, in order to record the length by digital pictures, using UTHSCSA ImageTool program (University of Texas Health Science Center, 1996). The recorded means of egg size were separated by Tukey test $(\mathrm{P}<0.05)$ and compared by one-way ANOVA using the statistical program SAS (SAS Institute, 2003).

Fecundity and longevity. The treatments used on theses trials were the same than in fertility and egg size. Insects selected were adult females; the experimental unit consisted of 10 insects, replicated four times. The insects had contact with active males in the artificial rearing, prior to selection and, before fungi spraying, were added three males for each 10 females for $24 \mathrm{~h}$ to increase fecundity possibilities. According to Oyarzún (2004) one male is capable to fecundate six females daily. All individuals were sprayed with $M$. anisopliae Qu-M984 at the doses mentioned above using a Potter spray tower. Before spraying the insects, they were placed in cylindrical flasks of $39 \mathrm{~mL}$ in groups of 10, later each insect was located separately in flasks of the same characteristics and fed with potato buds held at $23 \pm 1{ }^{\circ} \mathrm{C}$ in dark and $80 \% \pm$ R.H. Oviposition and mortality were individually recorded under stereomicroscope of $40 \mathrm{X}$, every $48 \mathrm{~h}$, until death of all insects. Fecundity of each female was determined 
counting number of eggs every $48 \mathrm{~h}$. To assess longevity mortality was recorded, considering dead insects those with no response to mechanical stimuli. The recorded means of fecundity and longevity were separated by Tukey test $(\mathrm{P}<0.05)$ and compared by one-way ANOVA using the statistical program SAS (SAS Institute, 2003).

\section{RESULTS AND DISCUSSION}

\section{Virulence}

The isolate studied demonstrated pathogenicity for all developmental stages when clumped together $(\mathrm{P} \leq$ $0.05)$, being mortality dose-dependent, mean values varying from $48 \%\left(10^{5}\right.$ conidia $\left.\mathrm{mL}^{-1}\right)$ to $78 \%\left(10^{8}\right.$ conidia $\mathrm{mL}^{-1}$ ), compared to $25.6 \%$ in the control (Figure 1). There were no differences among developmental stages $(\mathrm{P}>0.05)$ with the only exception when using the dose $10^{7}$ conidia $\mathrm{mL}^{-1}(\mathrm{P}<0.05)$ Likewise, there were differences $(\mathrm{P}<0.05)$ within doses for nymph II, nymph III, and adult developmental stages, although no difference was found for nymph I $(\mathrm{P}>0.05)$ (Table 1).

Lethal doses $\left(\mathrm{LD}_{50}\right)$ values ranged from $7.3 \times 10^{5}$ to $4.9 \times 10^{9}$ conidia $\mathrm{mL}^{-1}$ (adult and nymph I, respectively). Lethal time values at the higher dose $\left(10^{8}\right.$ conidia $\mathrm{mL}^{-1}$ ) ranged from 7.74 to $10 \mathrm{~d}$ among the different developmental stages (Table 2). All regression lines were verified and showed homogeneity for goodness of fit by $\chi^{2} . \mathrm{LT}_{50}$ obtained demonstrated that the dose $10^{8}$ conidia $\mathrm{mL}^{-1}$ decreased life time period in all developmental stages, affecting the reproductive potential of females prior to death, decreasing fertile period and oviposition time. There is no evidence of $\mathrm{TL}_{50}$ with entomopathogenic

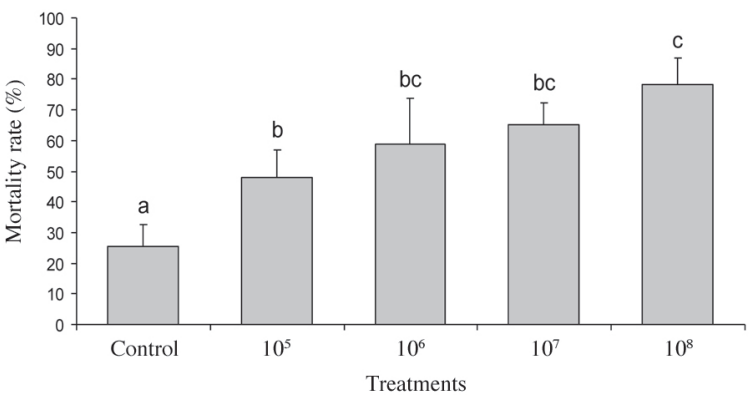

Distinct letters indicate differences according to Tukey test $(\mathrm{P}<0.05)$. SE: standard error

Figure 1. Mortality rate ( \pm SE) 19 d after aplication of Metarhizium anisopliae (conidia $\mathrm{mL}^{-1}$ ) for all developmental stages of Pseudococcus viburni.
Table 2. $\mathrm{LD}_{50}$ and $\mathrm{LT}_{50}$ of Metarhizium anisopliae isolate QU-M984 on the different developmental stages of Pseudococcus viburni.

\begin{tabular}{lll}
\hline Development stage & \multicolumn{1}{c}{$\mathrm{LD}_{50}$} & \multicolumn{1}{c}{$\mathrm{LT}_{50}$} \\
\hline & \multicolumn{1}{c}{ conidia $\mathrm{mL}^{-1}$} & $\mathrm{~d}$ \\
Nymph I & $4.9 \times 10^{9} \pm 3.93 \mathrm{NS}$ & $10.0 \pm 1.02 \mathrm{NS}$ \\
Nymph II & $7.3 \times 10^{6} \pm 3.75$ & $7.74 \pm 1.10$ \\
Nymph III & $4.7 \times 10^{6} \pm 4.19$ & $9.72 \pm 1.18$ \\
Adult & $7.3 \times 10^{5} \pm 4.02$ & $8.61 \pm 1.36$ \\
\hline
\end{tabular}

$\mathrm{LD}_{50}$ at $19 \mathrm{~d}$ post-inoculation; $\mathrm{LT}_{50}$ at $10^{8}$ conidia $\mathrm{mL}-1 ; \mathrm{NS}$ : non significant $(\mathrm{P}=0.05) ; \pm$ Standard error.

fungi and $P$. viburni, but authors have documented that Trialeurodes vaporariorum and Bemisia tabaci, treated with $B$. bassiana obtained $\mathrm{TL}_{50}$ ranging from 5.9 to $7.4 \mathrm{~d}$ with $10^{7}$ conidia $\mathrm{mL}^{-1}$ on fourth stage (Quesada-Moraga et al., 2006). Therefore, the highest dose used $\left(10^{8}\right.$ conidia $\mathrm{mL}^{-1}$ ) needed a short time to reach $50 \%$ mortality on all developmental stages of $P$. viburni, with similar values obtained by entomopathogenic fungi in insects of the same kind.

\section{Pre-lethal effects}

Fertility and egg size. No significant differences were found $(\mathrm{P}>0.05)$ (Table 3 ) in egg fertility and egg size. In fertility was recorded $94 \%, 95 \%$ and $93 \%$ of eclosed eggs (control, $10^{5}$ and $10^{6}$ conidia $\mathrm{mL}^{-1}$, respectively). The eggs of infected insects by entomopathogens can result in total or partial infertility, or contain infected embryos that will be inoculum for the dispersion of the pathogen (Alves and Pereira, 1998). In this study effects of decreasing egg fertility on survival females at doses of $10^{5}$ and $10^{6}$ conidia $\mathrm{mL}^{-1}$ were not detected. Similar results on egg fertility were observed on $B$. tabaci (Hemiptera: Aleyrodidae) and Leptinotarsa decemlineata (Coleoptera: Chrysomelidae) using $B$. bassiana (Fargues et al., 1991). Likewise, inoculating directly on eggs of Bemisia argentifolii with Verticillium lecanii Zimmermann, this showed no pathogenic effects, however all other developmental stages of the species were affected by the pathogen (Gindin et al., 2000). On the other hand, other studies have shown effects on egg fertility of survival females infected by M. anisopliae, as

Table 3. Mean ( \pm SE) total eggs, eggs $\mathrm{d}^{-1}$, and egg size for Pseudococcus viburni treated with Metarhizium anisopliae isolate QU-M984.

\begin{tabular}{llcl}
\hline $\begin{array}{l}\text { Dose } \\
\left(\text { conidia } \mathrm{mL}^{-1}\right)\end{array}$ & \multicolumn{1}{c}{$\begin{array}{c}\text { Total } \\
\text { eggs }\end{array}$} & $\begin{array}{c}\text { Eggs } \\
\mathrm{d}^{-1}\end{array}$ & \multicolumn{1}{c}{$\begin{array}{c}\text { Egg size } \\
(\mathrm{mm})\end{array}$} \\
\hline $10^{6}$ & $133.6 \pm 18.29 \mathrm{NS}$ & $13.4 \pm 2.16 \mathrm{NS}$ & $0.382 \pm 0.0023 \mathrm{NS}$ \\
$10^{5}$ & $120.4 \pm 18.46$ & $9.1 \pm 1.17$ & $0.376 \pm 0.0029$ \\
Control & $176.9 \pm 17.79$ & $12.3 \pm 1.18$ & $0.380 \pm 0.0021$ \\
\hline
\end{tabular}

NS: non significant $(P=0.05)$; SE: standard error.

Table 1. Virulence of Metarhizium anisopliae isolate QU-M984 on the different developmental stages of Pseudococcus viburni.

\begin{tabular}{|c|c|c|c|c|c|}
\hline \multirow[b]{2}{*}{ Development stage } & \multicolumn{5}{|c|}{ Dose $\left(\right.$ conidia $\mathrm{mL}^{-1}$ ) } \\
\hline & Control & $10^{5}$ & $10^{6}$ & $10^{7}$ & $10^{8}$ \\
\hline Nymph I & $37.5 \pm 4.8 \mathrm{aA}$ & $50.0 \pm 10.8 \mathrm{aA}$ & $62.5 \pm 21.7 \mathrm{aA}$ & $52.5 \pm 11.1 \mathrm{abA}$ & $65.0 \pm 8.7 \mathrm{aA}$ \\
\hline Nymph II & $25.0 \pm 5.0 \mathrm{aA}$ & $52.5 \pm 2.5 \mathrm{aABC}$ & $70.0 \pm 12.2 \mathrm{aBC}$ & $42.5 \pm 2.5 \mathrm{aAB}$ & $80.0 \pm 10.8 \mathrm{aC}$ \\
\hline Nymph III & $27.5 \pm 11.1 \mathrm{aA}$ & $40.0 \pm 5.8 \mathrm{aAB}$ & $52.5 \pm 12.5 \mathrm{aABC}$ & $85.0 \pm 6.5 \mathrm{cC}$ & $80.0 \pm 8.2 \mathrm{aBC}$ \\
\hline Adult & $12.5 \pm 4.8 \mathrm{aA}$ & $50.0 \pm 12.9 \mathrm{aAB}$ & $50.0 \pm 10.8 \mathrm{aAB}$ & $80.0 \pm 7.1 \mathrm{bcB}$ & $87.5 \pm 6.3 \mathrm{aB}$ \\
\hline
\end{tabular}

Means ( \pm SE) within a column followed by the same lower case letter and within row followed by the same upper case letter are not significantly different according to Tukey test $(\mathrm{P}=0.05)$ 
in the case of Megalurothrips sjostedti at concentrations of $10^{6}$ to $10^{8}$ conidia $\mathrm{mL}^{-1}$ (Ekesi and Maniania, 2000) and Cylas puncticollis at concentrations from $1 \times 10^{6}$ to $3.0 \times$ $10^{7}$ conidia $\mathrm{mL}^{-1}$ (Ondiaka et al., 2008).

Fecundity. Oviposition throughout the time reached a peak on the fourth day, and then decreased gradually, giving the same response in all treatments. No significant difference was found $(\mathrm{P}>0.05)(\mathrm{CV}=77 \%)$ (Figure $2)$. The total laid eggs counted throughout the lifetime of each adult female was 177 eggs to control, 134 eggs with $10^{6}$ and 120 with $10^{5}$ conidia $\mathrm{mL}^{-1}$. Likewise, in the number of eggs $\mathrm{d}^{-1}$ by female ranged among 9.1 and 13.4 eggs and no significant differences were found $(\mathrm{P}>0.05$, $\mathrm{CV}=83 \%$ ) (Table 3).

There was no effect of $M$. anisopliae isolate QuM984 on fecundity of P. viburni in the assessed doses. This could be due to sample heterogeneity, evidenced by the high coefficient of variation $(\mathrm{CV}=77 \%)$ not being possible to detect statistical differences. The distribution of the number of eggs laid throughout the female life span does not change among treatments when exposed to M. anisopliae (Figure 2), which differs to other studies where insects exposed to entomopathogenic fungi have shown higher initial number of eggs than the control, however, without statistical differences (Arthurs and Thomas, 2000; Pires et al., 2008). The development of a disease produced by a pathogen could be affected by biotic factors on the host, such as reproductive properties characteristics of the insect, population characteristics (individual susceptibility), and insect habits, among others (Alves and Lecuona, 1998). On the other hand, it should be considered the number of the individuals of the population inoculated, since the higher densities of insects increase the contact possibilities among them and consequently horizontal transmission, something that was not observed in this study, because the insects under study were isolated individuals. Also, the fitness of a specimen is directly dependent on the number of viable offspring produced, and both the pathogen and the host adopt strategies to maximize reproductive output (Baverstock et al., 2006; Roy et al., 2006). Also temperature can

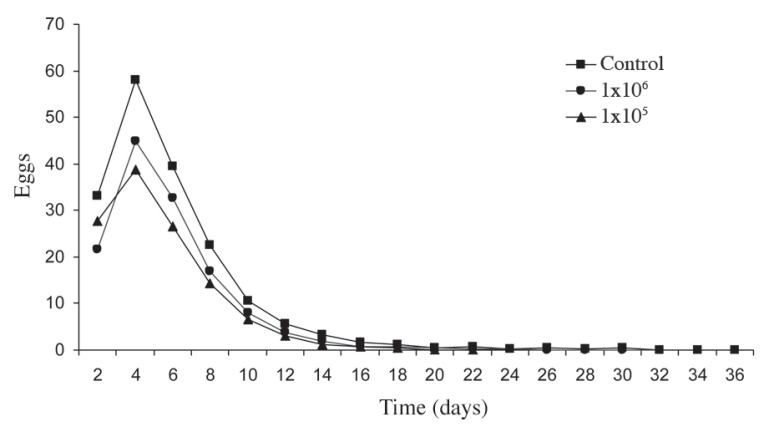

Figure 2. Mean eggs laid by adult females of Pseudococcus viburni exposed to Metarhizium anisopliae isolate Qu-M984. influence fecundity response. Leptinotarsa decemlineata treated with $B$. bassiana decreased its reproductive output at $23{ }^{\circ} \mathrm{C}$, but not at $25^{\circ} \mathrm{C}$ (Fargues et al., 1991). In our research this effect was not evaluated, since a constant 23 $\pm 1^{\circ} \mathrm{C}$ was used.

Any measurable behavior presents response thresholds and the form or magnitude often increases with dose (Hoy et al., 1998), therefore, it is possible that when doses are increased the reproductive output decreases. There are no registers of the effects of entomopathogens on P. viburni, however, it is possible to make comparisons with other insects. Similar results to this study were observed in the reproductive output of Tutta absoluta (Pires et al., 2008), using doses of $10^{7}$ conidia $\mathrm{mL}^{-1}$ of $M$. anisopliae and Diuraphis noxia (Wang and Knudsen, 1993) using B. bassiana. Other studies have shown positive results on this topic, for example Cylas puncticollis (Ondiaka et al., 2008), Anoplophora glabripennis (Hajek et al., 2008), Megalurothrips sjostedti (Ekesi and Maniania, 2000), among others.

Longevity. A significant difference was found in longevity of adult females among treatments $(\mathrm{P} \leq 0.05)$ (Table 4 , Figure 3 ). At $10^{6}$ conidia $\mathrm{mL}^{-1}$ there were differences compared to the control, however, no differences were detected between $10^{5}$ conidia $\mathrm{mL}^{-1}$ and control. With the dose $10^{6}$ conidia $\mathrm{mL}^{-1}$ was recorded a decrease of $11.8 \mathrm{~d}$ compared to the control $(29 \%)(\mathrm{CV}=62 \% ; \mathrm{P} \leq$ $0.05)$. The oviposition time was not significantly $(\mathrm{P}>$ $0.05)$ affected by the fungus, varying among 12 to 14.7 d (Table 4). Longevity of adult females was affected by M. anisopliae isolate $\mathrm{Qu}-\mathrm{M} 984$ at $10^{6}$ conidia $\mathrm{mL}^{-1}$. This could be the threshold concentration when the fungi start to affect longevity in females of the obscure mealybug. The decreased longevity at relatively low dose $\left(10^{6}\right.$

Table 4. Average ( \pm SE) longevity and oviposition time for Pseudococcus viburni treated with Metarhizium anisopliae isolate QU-M984.

\begin{tabular}{lll}
\hline Dose & Longevity rate & Oviposition time \\
\cline { 2 - 3 } conidia $\mathrm{mL}^{-1}$ & $29.62 \pm 2.25 \mathrm{a}$ & \\
\cline { 2 - 3 } $10^{6}$ & $35.68 \pm 2.30 \mathrm{ab}$ & $12.06 \pm 1.29 \mathrm{a}$ \\
$10^{5}$ & $41.43 \pm 1.36 \mathrm{~b}$ & $12.18 \pm 1.03 \mathrm{a}$ \\
Control & & $14.74 \pm 1.11 \mathrm{a}$ \\
\hline
\end{tabular}

d: days after treatment, SE: standard error. Means within columns followed by the same letters are not significantly different according to Tukey test $(\mathrm{P}=0.05)$.

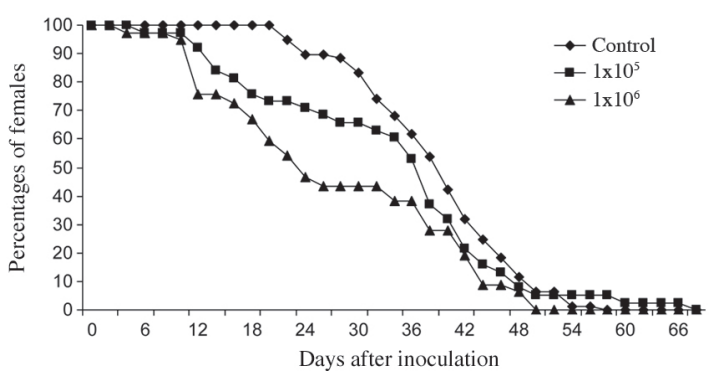

Figure 3. Longevity of adult females of Pseudococcus viburni treated with Metarhizium anisopliae isolate QU-M984. 
conidia $\mathrm{mL}^{-1}$ ), reduces the direct damage caused by the insect, which does not have economic importance, but takes relevance when decreasing possibilities to find live quarantine insects at the moment of harvest. Similar results to this study were obtained with Diuraphis noxia Kurdiumov, when pre-lethal effects of entomopathogenic fungi were evaluated and found effects only on longevity (Wang and Knudsen, 1993).

\section{CONCLUSIONS}

Metarhizium anisopliae var. anisopliae isolate Qu-M984 demonstrated pathogenicity for Pseudococcus viburni, under controlled laboratory conditions. Virulence was dose-dependent and showed high mortality in short term. Low doses of the isolate do not affect pre-lethal reproductive effects, such as fecundity, fertility and egg size, however, longevity is affected to a low dose. These results showed that $M$. anisopliae isolate Qu-M984 is an option to control this pest; nevertheless research at field conditions is needed.

\section{ACKNOWLEDGEMENTS}

We would like to thank Maritza Tapia and Lionel Finot for critical review of the manuscript. And we would also like to thank Ricardo Ceballos and Marisol Berti for assistance with the statistical analysis. This study was supported by INIA Quilamapu, Chillán, Chile, and INNOVA Chile.

\section{Virulencia y efectos pre-letales en la reproducción de Metarhizium anisopliae var. anisopliae en Pseudococcus viburni (Hemiptera: Pseudococcidae).} Chanchito blanco de la vid, Pseudococcus viburni (Signoret), es una plaga cosmopolita que causa daños tanto por succión de jugos vasculares como por su producción de mielecilla, así como también por ser un insecto cuarentenario. Dentro de las opciones de control, hongos entomopatógenos son una buena alternativa, sin embargo, más investigación es necesaria. En esta investigación fue evaluado Metarhizium anisopliae var. anisopliae (Metschnikoff) aislamiento Qu-M984 en P. viburni bajo condiciones de laboratorio. Fue evaluada virulencia según dosis letal $50\left(\mathrm{LD}_{50}\right)$ y tiempo letal $50\left(\mathrm{LT}_{50}\right)$ para cada uno de los cuatro estados de desarrollo de la hembra. Las dosis evaluadas fueron $10^{5}, 10^{6}, 10^{7}$ y $10^{8}$ conidias $\mathrm{mL}^{-1}$. Fecundidad, tamaño de huevos, fertilidad y longevidad de hembras adultas fueron evaluados con dosis $10^{5}$ y $10^{6}$ conidias $\mathrm{mL}^{-1}$, las evaluaciones fueron realizadas cada 2 d durante todo el período de vida de los insectos. Las $\mathrm{LD}_{50} \mathrm{y} \mathrm{LT}_{50}$ obtenidas fueron variables para cada estado de desarrollo, sin mostrar diferencias significativas $(\mathrm{P}>$ 0.05 ) entre estados de desarrollo, fluctuando entre $\mathrm{LD}_{50}$ $=7.3 \times 10^{5}-4.9 \times 10^{9}$ conidias $\mathrm{mL}^{-1}$ y $\mathrm{LT}_{50}=7.74-9.97$ $\mathrm{d}$ con $10^{8}$ conidias $\mathrm{mL}^{-1}$. Diferencias significativas $(\mathrm{P} \leq$ $0.05)$ fueron observadas en longevidad a $10^{6}$ conidias $\mathrm{mL}^{-1}$. Longevidad fue $29 \%$ menor comparado con el testigo. Esta disminución en longevidad a una dosis relativamente baja es relevante debido a que disminuyen las posibilidades de encontrar insectos cuarentenarios vivos al momento de cosecha. Fertilidad, fecundidad y tamaño de huevos no mostraron diferencias $(\mathrm{P}>0.05)$.

Palabras clave: dosis letal, tiempo letal, control biológico, hongo entomopatógeno, fecundidad, fertilidad, longevidad.

\section{LITERATURE CITED}

Abbott, W.S. 1925. A method of computing the effectiveness of an insecticide. Journal of Economy Entomology 18:265-267.

Alves, S.B., e R.E. Lecuona. 1998. Epizootiologia aplicada ao controle microbiano de insetos. p. 97-165. In S.B. Alves (ed.) Controle microbiano de insetos. 2a ed. FEALQ, Piracicaba, Brazil.

Alves, S.B., e R.M. Pereira. 1998. Distúrbios fisiológicos provocados por entomopatógenos. p. 39-54. In S.B. Alves (ed.) Controle microbiano de insetos. 2a ed. FEALQ, Piracicaba, Brazil.

Arthurs, S., and M. Thomas. 2000. Effects of a mycoinsecticide on feeding and fecundity of the Brown Locust Locustana pardalina. Biocontrol Science and Technology 10:321-329.

Artigas, J. 1994. Entomología económica: insectos de interés agrícola, forestal, médico y veterinario (nativos, introducidos y susceptibles de ser introducidos). Vol. 1. 1250 p. Ediciones Universidad de Concepción, Concepción, Chile.

Baverstock, J., H. Roy, S. Clark, P. Alderson, and J. Pell. 2006. Effect of fungal infection on the reproductive potential of aphids and their progeny. Journal of Invertebrate Pathology 91:136-139.

Blanford, S., and M. Thomas. 2001. Adult survival, maturation, and reproduction of the Desert Locust Schistocerca gregaria infected with the fungus Metarhizium anisopliae var acridum. Journal of Invertebrate Pathology 78:1-8.

Bournier, A. 1976. Grape insects. Annual Review of Entomology 22:355-376

Butt, T.M., and M.S. Goettel. 2000. Bioassays of entomogenous fungi. p. 141-195. In Navon, A., and K.R. Ascher (eds.) Bioassays of entomopathogenic microbes and nematodes. CABI Publishing, Wallingford, UK

Castillo, M.-A., P. Moya, E. Hernández, and E. Primo-Yúfera. 2000. Susceptibility of Ceratitis capitata Wiedemann (Diptera: Tephritidae) to entomopathogenic fungi and their extracts. Biological Control 19:274-282.

Ekesi, S., and N.K. Maniania. 2000. Susceptibility of Megalurothrips sjostedti developmental stages to Metarhizium anisopliae and the effects of infection on feeding, adult fecundity, egg fertility and longevity. Entomologia Experimentalis et Applicata 94:229-236.

Fargues, J., J.-C. Delmas, J. Augé, and R. Lebrun. 1991. Fecundity and egg fertility in the adult Colorado beetle (Leptinotarsa decemlineata) surviving larval infection by the fungus Beauveria bassiana. Entomologia Experamentalis et Applicata 61:45-51.

Ferron, P. 1978. Biological control of insect pests by entomogenous fungi. Annual Review of Entomolology 23:409-442.

Gindin, G., N. Geschtovt, B. Raccah, and I. Barash. 2000. Pathogenicity of Verticillium lecanii to different developmental stages of the Silverleaf Whitefly, Bemisia argentifolii. Phytoparasitica 28:229-239.

González, R.H. 1989. Insectos y ácaros de importancia agrícola y cuarentenaria en Chile. Ograma, Santiago, Chile.

González, R.H. 2003a. Chanchitos blancos de importancia agrícola y cuarentenaria, en huertos frutales de Chile (Hemiptera: Pseudococcidae). Revista Frutícola 24:5-17.

González, R.H. 2003b. Manejo cuarentenario de chanchitos blancos de pomáceas en Chile (Hemiptera: Pseudococcidae). Revista Frutícola 24:89-98.

González, R.H., J. Poblete, y G. Barría. 2001. El chanchito blanco de los frutales en Chile, Pseudococcus viburni (Signoret), 
(Homoptera: Pseudococcidae). Revista Frutícola 22:17-26.

González, R.H., y C. Volosky. 2006. Desarrollo estacional y estrategias de manejo de chanchitos blancos, Pseudococcus spp., en pomáceas, uva de mesa y vid vinífera (Hemiptera: Pseudococcidae). Revista Frutícola 27:37-47.

Hajek, A., J. Lund, and M. Smith. 2008. Reduction in fitness of female Asian longhorned beetle (Anoplophora glabripennis) infected with Metarhizium anisopliae. Journal Invertebrate Pathology 98:198-205.

Hoy, C., G. Head, and F. Hall. 1998. Spatial heterogeneity and insect adaptation to toxins. Annual Review of Entomolology 43:571594.

Lacey, L., R. Frutos, H. Kaya, and P. Vail. 2001. Insect pathogens as biological control agents: Do they have a future? Biological Control 21:230-248.

Ondiaka, S., N. Maniania, G. Nyamasyo, and J. Nderitu. 2008. Virulence of the entomopathogenic fungi Beauveria bassiana and Metarhizium anisopliae to sweet potato weevil Cylas puncticollis and effects on fecundity and egg viability. Annals of Applied Biology 153:41-48.

Oyarzún, M. 2004. Taxonomía y observaciones biológicas del chanchito blanco de los frutales, Pseudococcus viburni (Signoret). (Hemiptera: Pseudococcidae). Tesis Ingeniero Agrónomo. Universidad de Chile, Facultad de Ciencias Agronómicas, Escuela de Agronomía, Santiago, Chile.

Pires, L., E. Marques, V. Wanderley-Teixeira, Á. Teixeira, L. Alves, and E. Alves. 2008. Ultrastructure of Tuta absoluta parasitized eggs and the reproductive potential of females after parasitism by Metarhizium anisopliae. Micron 40:255-261.
Quesada-Moraga, E., E.A.A. Maranhao, P. Valverde-García, and C. Santiago-Álvarez. 2006. Selection of Beauveria bassiana isolates for control of the whiteflies Bemisia tabaci and Trialeurodes vaporariorum on the basis of their virulence, thermal requirements, and toxicogenic activity. Biological Control 36:274-287.

Quesada-Moraga, E., R. Santos-Quirós, P. Valverde-García, and C. Santiago-Álvarez. 2004. Virulence, horizontal transmission, and sublethal reproductive effects of Metarhizium anisopliae (Anamorphic fungi) on the German cockroach (Blattodea: Blattellidae). Journal of Invertebrate Pathology 87:51-58.

Roy, H., D. Steinkraus, J. Eilenberg, A. Hajek, and J. Pell. 2006. Bizarre interactions and endgames: Entomopathogenic fungi and their arthropod hosts. Annual Review of Entomology 51:331-357.

SAS Institute. 2003. SAS system. Version 9.1. SAS Institute, Cary, North Carolina, USA.

Scholte, E.-J., B. Knols, and W. Takken. 2006. Infection of the malaria mosquito Anopheles gambiae with the entomopathogenic fungus Metarhizium anisopliae reduces blood feeding and fecundity. Journal of Invertebrate Patholology 91:43-49.

Statgraphics. 2000. Statistical Graphics Corporation Statgraphics Plus. Version 5.0. Manugistics Inc., Rockville, Maryland, USA.

University of Texas Health Science Center. 1996. UTHSCSA ImageTool. Version 3. University of Texas Health Science Center, San Antonio, Texas, USA. Available at http://ddsdx.uthscsa.edu/ dig/itdesc.html (accessed August 2011).

Wang, Z.G., and G.R. Knudsen. 1993. Effect of Beauveria bassiana (Fungi: Hyphomycetes) on fecundity of the Russian wheat aphid (Homoptera: Aphididae). Environmental Entomology 22:874878 . 